\title{
MORPHOFUNCTIONAL MODIFICATION IN ELDERLY INDIVIDUALS PRACTICING COMPETITIVE ENDURANCE SPORT
}

\author{
Alessio Sullo $^{1,2}$, Guglielmo Brizzi ${ }^{2}$, Pasquale Cardinale ${ }^{1}$, Bruno Fabbri ${ }^{3}$, Nicola Maffulli ${ }^{4}$
}

\begin{abstract}
Operative United of Rehabilitation and Care - "Lungodegenza Division” - ASL AV1, S. Nicola Baronia, Italy1; Second University of Naples, Medical School, Napoli, Italy: Department of Experimental Medicine, Section of Physiology2; Sport Medicine Center CONI-FMSI - Padova, Italy ${ }^{3}$; Keele University School of Medicine, North Staffordshire Hospital, England: Department of Trauma and Orthopaedic Surgery ${ }^{4}$
\end{abstract}

\begin{abstract}
Summary: To investigate the modification of body composition and level of aerobic capacity in older athletes practicing competitive sport for two years consecutively, 20 elderly male endurance athletes (A) were compared with twenty elderly male subjects who practiced moderate exercise $(\mathrm{C})$. Body composition analysis, physical activity and maximal aerobic power $\left(\mathrm{VO}_{2 \max }\right)$ were measured at the beginning of the study, after twelve months and after twenty-four months in both groups. We observed significant differences in group A: body fat was significantly lower in the subjects at the first and second year than at the beginning of the study; fat-free mass (FFM) was significantly higher in the subjects at the first and second year; $\mathrm{VO}_{2 \max }$ in every measurements was significantly higher in the subjects at the at the first and second year than at beginning of the study. Our data suggest that it is possible, even in the elderly, to reach a good level of physical fitness with appropriate training protocols for competitive sport.
\end{abstract}

Key words: Body composition; Cardiovascular fitness; Physical training; Aerobic power; Older athletes

\section{Introduction}

Several investigators have studied the effects of physical activity and aging $(10,13,16)$. The marked benefits of moderate physical exercise on cardiovascular function, particularly in subjects of middle and advanced age, are well known, but serious worries on the effects of competitive sports activity in this age group have been reported $(1,16,19)$.

The decreased physical performance in elderly it is due to various factors. One of these is the hipokinetic syndrome, a condition not well defined but seemingly caused by physical inactivity. Several investigators have studied the effects of training in elderly $(2,20)$, and tried to ascertain the effects of training in contrast to the effects of deconditioning induced by ageing (3).

Aging is characterized by loss of fat-free mass (FFM). These age-related changes probably vary in rate, timing and extent between subjects according to differences in leisure or occupational physical activity, disease and several other factors (11). The effects of endurance training on aerobic power were studied longitudinally $(7,12,14,15)$. These studies have suggested that endurance training could increase aerobic power in older subjects.

This study investigated the changes in body composition and aerobic power in a group of older athletes who practiced competitive sport for two consecutive years com- paring them with a control group of subjects with similar characteristics who practiced moderate physical activity.

\section{Material and Methods}

All procedures were performed after local Ethics Committee approval had been granted. All patients taking part in this study gave written informed consent.

\section{Subjects}

Twenty elderly male endurance athletes aged $65 \pm 2.6$ who attended our institution to obtain a medical certificates for eligibility to compete in their age group were included in this study (group A). These athletes were compared with twenty male subjects aged $66 \pm 1.3$ who attended our institution for a sample control because they practiced moderate recreational exercise (control group).

All subjects completed a medical questionnaire. No subject had experienced significant changes in body weight, and had positive familiar and personal history for ischemic heart disease.

All the subjects (group A and C) at the first visit had a low aerobic power related to fat-free mass (FFM): $\left(\mathrm{VO}_{2 \max }<55 \mathrm{ml}^{*} \mathrm{~kg} \mathrm{FFM}^{-1 *} \min ^{-1}\right)$. 


\section{Anthropometric measurements and body composition analysis}

Body mass of each subject was measured with a Toledo Weight-Plate to the nearest 0.1 kilogram after an overnight fast immediately after morning micturition. Naked body mass was calculated as total body mass minus robe and hospital gown mass. The height of subjects was measured without shoes to the nearest $0.1 \mathrm{~cm}$ with a wall-mounted stadiometer. Body mass index (BMI) was calculated as $\mathrm{wt} / \mathrm{ht}^{2}\left(\mathrm{~kg} / \mathrm{m}^{2}\right)$.

Body composition was measured by using bioelectrical impedance analysis (BIA) with a Xitron 4000 Bioimpedance Analyzer (Xitron Technologies, San Diego). BIA measurements were taken at the same time of the RMR measurements under the following conditions: subjects after 12 hours of fasting, immediately after morning micturition and after drinking $250 \mathrm{ml}$ of water. With the subject supine, the receiving electrodes were placed on the dorsal parts of the right wrist and right ankle, while the stimulating electrodes were placed on the dorsum of the right foot and right hand. The resistance $(\mathrm{R})$ was measured three times, and the mean of these three measurements was used for subsequent calculations. FFM was calculated by using the predictive Lohman equation (9). Fatty mass (FM) was calculated as the difference between the total body mass (BW) and FFM. The percentage of body fat (BF\%) was evaluated as $(\mathrm{BM}-\mathrm{FFM}) * \mathrm{BM}^{-1}$, and total body water (TBW) was calculated as $\mathrm{FFM}^{*} 0.73$. Anthropometric measurements and body composition analysis of each subject were done at beginning of the study and for two consecutive years in occasion of visit to obtain a medical certificates for eligibility.

\section{Dietary analysis}

Each subject recorded his weighed intake of food for 7 consecutive days after having received formal training by one of the researchers involved in the study (AS). Food composition was calculated with a computer program using the information provided by L.A.R.N. (8).

Dietary analysis of each subject was measured at beginning of the study and for two consecutive years.

\section{Physical activity}

To describe the physical activity of the subjects during the year before the study, we collected information about the type, duration, intensity and frequency (daily and monthly) of the exercise regime that each subject followed.

The physical stress induced by each activity was classified by using a scale with 5 levels, where the first level was very low activity (calm breathing) and the fifth level very heavy activity (heavy breathing).

Physical activity of each subject was measured at beginning of the study and for two consecutive years.

\section{Determination of $\mathrm{VO}_{2 \max }$}

$\mathrm{VO}_{2 \max }$ was determined using an electrically driven treadmill and an open circuit gas analysis system (Radiometer Copenaghen). After a 10- to 15-min warm up at a self-selected comfortable running speed, each subject started the test running horizontally at $15 \mathrm{~km}^{*} \mathrm{~h}^{-1}$. Running speed was kept constant, and the slope was increased by $1^{\circ}$ every min until exhaustion. During the test, heart rate was monitored using a commercially available heart rate monitor (Esaote).

Determination of $\mathrm{VO}_{2}$ max of each subject was measured at beginning of the study and for two consecutive years.

\section{Statistical analysis}

Descriptive statistics is reported. Values are given as means \pm SEM. The analysis of differences among the three groups was performed by analysis of variance (ANOVA). Tukey post hoc test was used to determine significant differences for $\mathrm{p}<0.05$

\section{Results}

The subjects' characteristics in the three visits for eligibility (group A) are presented in Tab. 1. There were significant differences among the three measurements: body fat was significantly lower in the first and second year $(p<0.05)$; FFM was significantly higher in the subjects at the first and second year than at beginning of the study $(p<0.05)$; Resting heart rate (RHR) was significantly lower in the subjects at the first and second year than at the at beginning of the study $(\mathrm{p}<0.05)$; $\mathrm{VO}_{2}$ max in every measurement was significantly higher in the subjects at the first and second year than at beginning of the study $(p<0.01)$. There were no significant differences among the three year measurements for BMI and maximal heart rate (MHR). No significant differences were found between the measurement of body fat, FFM, RHR, MHR and $\mathrm{VO}_{2 \max }$ in every measurement in the subjects at the first and second year.

Tab. 2 shows the characteristics the of control group for the duration of the study. No significant differences were found in $\mathrm{VO}_{2 \max }, \mathrm{BMI}, \mathrm{BF} \%$ and FFM in the period of observation while also in this group found a significant decrease $(p<0.05)$ of RHR.

Dietary analysis of daily total energy intake and daily mean macronutrients intake of group $A$ are reported in Tab. 3. After two years, the athletes in group A reported a daily energy intake about $500 \mathrm{kcal}$ higher than those of first years and at beginning of the study $(p<0.05)$. The higher energy intake resulted from higher carbohydrate and protein consumption. Owing to the higher total energy intake, there are no significant differences among the three measurement for carbohydrate and protein intake when they are reported as percentage of total energy intake.

Dietary analysis of daily total energy intake and daily mean macronutrients intake of the control group are shown 
Tab. 1: Physical characteristics of the athletes of Group $\mathrm{A}(\mathrm{X} \pm \mathrm{SEM})$.

\begin{tabular}{|c|c|c|c|}
\hline \begin{tabular}{|l} 
VARIABLE \\
\end{tabular} & Baseline & I year & II year \\
\hline $\begin{array}{l}\text { Body Mass Index } \\
\left(\mathrm{Wt}^{*}\left(\mathrm{Ht}^{2}\right)^{-1}\right)\end{array}$ & $25.7 \pm 1.7$ & $24.7 \pm 0.9$ & $24.2 \pm 1.8$ \\
\hline Body fat $(\%)^{\mathrm{a}}$ & $27.1 \pm 0.9$ & $24.3 \pm 1.8$ & $22.5 \pm 2.0$ \\
\hline Fat free mass $(\mathrm{kg})^{\mathrm{b}}$ & $53.1 \pm 2.0$ & $58.4 \pm 2.8$ & $60.3 \pm 3.3$ \\
\hline $\begin{array}{l}\text { Resting heart rate } \\
\left(\text { beat* } \min ^{-1}\right)^{a}\end{array}$ & $77.1 \pm 2.3$ & $62.3 \pm 1.3$ & $58.3 \pm 1.6$ \\
\hline $\begin{array}{l}\text { Maximal heart rate } \\
\left(\text { beat* } \min ^{-1} \text { ) }\right.\end{array}$ & $174.43 \pm 3.6$ & $170.13 \pm 4.0$ & $169.1 \pm 3.5$ \\
\hline $\mathrm{VO}_{2 \max }\left(1^{*} \min ^{-1}\right)^{\mathrm{c}}$ & $2.6 \pm 0.12$ & $3.02 \pm 0.12$ & $3.3 \pm 0.13$ \\
\hline \begin{tabular}{|l|}
$\mathrm{VO}_{2 \max }$ \\
$\left(\mathrm{ml}^{*} \min ^{-1 *} \mathrm{~kg}^{-1}\right)^{\mathrm{c}}$
\end{tabular} & $39.8 \pm 2.4$ & $44.9 \pm 1.5$ & $52.0 \pm 4.0$ \\
\hline $\begin{array}{l}\mathrm{VO}_{2 \max } \\
\left(\mathrm{ml}^{*} \mathrm{~kg}^{-1} \mathrm{FFM}^{*} \min ^{-1}\right)^{\mathrm{c}}\end{array}$ & $49.6 \pm 1.7$ & $57.8 \pm 1.4$ & $61.8 \pm 3.0$ \\
\hline $\begin{array}{l}\text { Physical activity } \\
\left(\text { kcal }^{*} \text { day }^{-1}\right)\end{array}$ & $630 \pm 152$ & $752 \pm 98$ & $825 \pm 154$ \\
\hline
\end{tabular}

${ }^{\mathrm{a}}$ Baseline $>$ I and II years $(\mathrm{p}<0.05) ;{ }^{\mathrm{b}}$ Baseline $<$ I and II years $(\mathrm{p}<0.05)$

${ }^{\mathrm{c}}$ Baseline $<$ I and II years $(\mathrm{p}<0.01)$

Tab. 2: Physical characteristics of the subjects of Group $\mathrm{C}$ (control) $(\mathrm{X} \pm \mathrm{SEM})$.

\begin{tabular}{|c|c|c|c|}
\hline VARIABLE & Baseline & I year & II year \\
\hline $\begin{array}{l}\text { Body Mass Index } \\
\left(\mathrm{Wt}^{*}\left(\mathrm{Ht}^{2}\right)^{-1}\right)\end{array}$ & $25.7 \pm 0.7$ & $25.4 \pm 0.9$ & $25.0 \pm 0.8$ \\
\hline Body fat (\%) & $26.1 \pm 0.9$ & $26.0 \pm 1.8$ & $25.2 \pm 2.0$ \\
\hline Fat free mass $(\mathrm{kg})$ & $54.9 \pm 2.0$ & $55.4 \pm 2.8$ & $56.3 \pm 3.3$ \\
\hline $\begin{array}{l}\text { Resting heart rate } \\
\left(\text { beat* } \min ^{-1}\right)^{\mathrm{a}}\end{array}$ & $75.1 \pm 2.3$ & $64.3 \pm 1.3$ & $63.3 \pm 1.6$ \\
\hline 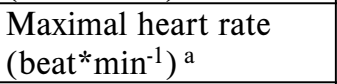 & $184.43 \pm 3.6$ & $170.13 \pm 4.0$ & $159.1 \pm 3.51$ \\
\hline $\mathrm{VO}_{2 \max }\left(1 * \min ^{-1}\right)$ & $2.4 \pm 0.12$ & $2.3 \pm 1.12$ & $2.4 \pm 0.13$ \\
\hline $\mathrm{VO}_{2 \max }\left(\mathrm{ml}^{*} \min ^{-1 *} \mathrm{~kg}^{-1}\right)$ & $38.8 \pm 2.4$ & $38.4 \pm 1.5$ & $39.0 \pm 4.0$ \\
\hline $\begin{array}{l}\mathrm{VO}_{2 \max } \\
\left(\mathrm{ml}^{*} \mathrm{~kg}^{-1} \mathrm{FFM}^{*} \mathrm{~min}^{-1}\right)\end{array}$ & $50.6 \pm 1.7$ & $49.8 \pm 1.4$ & $51.8 \pm 3.0$ \\
\hline $\begin{array}{l}\text { Physical activity } \\
\left(\mathrm{kcal}^{*} \text { day }^{-1}\right)\end{array}$ & $630 \pm 172$ & $650 \pm 205$ & $625 \pm 124$ \\
\hline
\end{tabular}

${ }^{\text {a }}$ Baseline $>$ I and II years $(\mathrm{p}<0.05)$

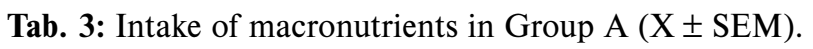

\begin{tabular}{|l|c|c|c|}
\hline VARIABLE & Baseline & I year & II year \\
\hline Kcal $^{*}$ day $^{-1}$ & $1598 \pm 125$ & $1608 \pm 112$ & $2084 \pm 182$ \\
\hline Carbohydrates (g) $^{-1}$ & $220.5 \pm 31.1$ & $240.5 \pm 23.1$ & $348.8 \pm 44.3$ \\
\hline Carbohydrates (\%) & $56.1 \pm 1.2$ & $58.1 \pm 2.5$ & $61.2 \pm 1.2$ \\
\hline Fats (g) & $54.1 \pm 7.2$ & $52.8 \pm 6.1$ & $50.8 \pm 8.0$ \\
\hline Fats (\%) & $30.7 \pm 2.0$ & $26.3 \pm 3.0$ & $21.9 \pm 2.5$ \\
\hline Proteins (g) & $57.0 \pm 6.1$ & $68.6 \pm 5.0$ & $91.5 \pm 7.0$ \\
\hline Proteins (\%) & $14.8 \pm 1.9$ & $15.9 \pm 2.3$ & $16.3 \pm 2.1$ \\
\hline
\end{tabular}

Baseline $<$ I and II years $(\mathrm{p}<0.05)$
Tab. 4: Intake of macronutrients in Group C (X \pm SEM).

\begin{tabular}{|l|c|c|c|}
\hline VARIABLE & Baseline & I year & II year \\
\hline Kcal $^{*}$ day $^{-1}$ & $1602 \pm 125$ & $1588 \pm 135$ & $1612 \pm 115$ \\
\hline Carbohydrates $(\mathrm{g})^{-1}$ & $220.5 \pm 31.1$ & $223.5 \pm 31.1$ & $222.5 \pm 31.1$ \\
\hline Carbohydrates $(\%)$ & $57.1 \pm 1.2$ & $56.1 \pm 1.2$ & $54.1 \pm 1.2$ \\
\hline Fats (g) & $54.1 \pm 7.2$ & $54.1 \pm 7.2$ & $54.1 \pm 7.2$ \\
\hline Fats (\%) & $31.7 \pm 2.0$ & $30.7 \pm 2.0$ & $31.7 \pm 2.0$ \\
\hline Proteins (g) & $57.2 \pm 6.1$ & $58.0 \pm 4.1$ & $57.0 \pm 7.1$ \\
\hline Proteins (\%) & $14.7 \pm 2.2$ & $15.8 \pm 0.9$ & $13.8 \pm 2.4$ \\
\hline
\end{tabular}

in Tab. 4. No significant differences were found for the control group for daily Kcal or percentage intake of macronutrients.

\section{Discussion and Conclusion}

Physical training in the age range considered has not been widely researched, and may represent a challenge for sport physicians. Our results are in accordance with other investigations $(4,17,18)$. Zeppilli et al. (21) demonstrated that training improved cardiovascular fitness both in young and elderly people. This improvement was proportional to the intensity of endurance training, and was more evident when pre-training $\mathrm{VO}_{2 \max }$ was lower. In our study, no significant differences were found in the control group between the beginning and the end of the observation period, as the subjects in this group were not sedentary, but practiced moderate recreational physical activity.

Other investigations showed that an increase in $\mathrm{VO}_{2 \max }$ was already evident after six months of moderate physical activity $(4,17,18)$. Steinhaus et al. (17) evaluated the effects of a four month aerobic conditioning program in old previously sedentary individuals, finding an increase of $27 \%$ in $\mathrm{VO}_{2 \max }$ similarly to other authors $(4,18)$. Others authors studied longitudinally the effects of endurance training on aerobic power suggesting that endurance training could increase aerobic power in older subjects $(7,12,14,15)$.

This study shows that endurance training in elderly individuals produces cardiovascular adaptation (5). In normal subjects, training shows three stages of progression: initial conditioning, improvement, and maintenance. The initial stage of conditioning provides for an aerobic activity of low intensity for evaluation of cardiorespiratory fitness (first year, control group). At the end of the observation period, the subjects had a high level of cardiorespiratory fitness. During the stage of improvement, the subjects in the first year increased their aerobic power, reaching in percentage the same improvements as a young athlete.

Our data suggest that it is possible, also in the elderly, to reach a good level of physical fitness with appropriate training protocols for competitive sport. This finding supports the hypothesis that the progressive reduction in physical activity with aging is a main reason for the decreased functional capacity in the elderly. 


\section{References}

1. Astrand PO. Physical activity and fitness. Am J Clin Nutr 1992;55(6):1231S-S36

2. Badenhop D, Cleary PA, Schaal SF, Fox EL, Bartels R. Physiological adijustmen to higher or lower exercise in elder. Med Sci Sports Exerc 1983;15(6):496-502.

3. Carlucci D, Goldfine H, Ward A, Taylor P, Rippe JM. Exercise: not just for the healty. Phys Sports Med 1991;19:46-51.

4. Devis JA Franch MH, Wipp BJ. Anaerobic thresold alteration caused by endurance training in middle-aged men. J Appl Physiol 1979;46:1039-41.

5. Eduards K, Larson EB: Benefit of exercise for older adults. A review of existing evidence and current recommendations for the general population. Clin Geriatr Med 1982;8:35-8.

6. Greig CA, Young A, Skelton DA, Pippet E, Butler FM, Mahrnoud SM. Exercise studies with elderly volunteers. Age Aging 1994;23:185-8.

7. Kohrt WM, Malley MT, Coggan AR et al. Effects of gender, age, and fitness level on response of VO2max to training in 60-71 yr olds. J Appl Physiol 1991; 71(5):2004-11.

8 L.A.R.N. Livelli raccomandati di nutrienti per gli italiani. S.I.N.U., 1995.

9. Lohman TG, Going SB, Golding L et al. Interlaboratory bioelectric resistance comparision. Med Sci Sports Exerc 1987;19:540.

10. Massč-Biron J, Mercier J, Collomp K, Hardy JM, Prefaut C. Age and training effects on lactate kinetics of master athletes during maximal exercise. Eur J Appl Physiol 1992; 65:311-5.

11. Murray LA, Reilly JJ, Choudhry M, Durnin JV. A longitudinal study of changes in body composition and basal metabolism in physically active elderly men. Eur J Appl Physiol Occup Physiol 1996;72(3):215-8.

12. Posner JD, Gorman KM, Windsor-Landsberg L et al. Low to moderate intensity endurance training in healthy older adults: physiological responses after four months. J Am Geriatr Soc 1992;40:1-7.

13. Rivera AM, Pels AE, Sady MA, Cullinane EM, Thompson PD. Physiological factors associated with the lower maximal oxigen consuption of master runners. J Appl Physiol 1989;66:949-53.
14. Schwartz RS, Shuman WP, Larson V et al. The effect of intensive endurance exercise training on body fat distribution in young and older men. Metabolism 1991;40(5):545-51

15. Schwartz RS, Cain KC, Shuman WP et al. Effect of intensive endurance training on lipoprotein profiles in young and older men. Metabolism 1992;41(6):649-54 16. Shepard RJ, Sidney KH. Exercise and aging. Exerc Sport Sci Rev 1978; 6:1-5.

17. Steinhaus LA, Dustman RE, Ruhling RO. Aerobic capacity of older adult: a training study. J Sport Med Phys Fitness 1990;30:163-6.

18. Stratton JR, Levy WC, Cerqueira MD, Schwartz RS, Abrass IB. Cardiovascular responses to exercise. Effects of aging and exercise training in healty men. Circulation 1985;89:1648-52.

19. Warren BJ, Nieman DC, Dotson RG. Cardiorespiratory responses to exercise training in septuagenarian women. Int J Sports Med 1993;14:60-5.

20. Young A. Skelton DA. Applied physiology of strength and power in old age. Int Sports Med 1994;15:149-51.

21. Zeppilli P, Manno V, Cameli S. Effetti dell'allenamento dell'atletica leggera sul cuore di atleti ultraquarantenni. Giornale di riabilitazione 1987;2:105-9.

Submitted August 2003.

Accepted October 2003.

Dott. Alessio Sullo, U.O. Riabilitazione e Cura, Divisione di Lungodegenza, ASL AV1, Via Vittorio Veneto 1, 83050 S. Nicola Baronia (AV),

Italy. e-mail: alessiosullo@virgilio.it 